\title{
Ownership structure and minority expropriation: the case for multiple blockholders
}

\author{
María Gutiérrez, Josep A. Tribó* and Beatriz Mariano \\ Department of Business Administration, Universidad Carlos III, C/ Madrid \\ 126, 28903 Getafe, Spain
}

This article investigates minority expropriation in closely-held firms. Using a sample of Spanish firms for the period from 1996 to 2006, we find that firms that are more vulnerable to minority expropriation have blockholders controlling groups with aggregate equity stakes that are far removed from $50 \%$, which is the point that maximizes the chances of expropriation. Moreover, performance improves when the controlling group's stake moves away from the region where expropriation is more likely - the alignment effect - and, if within this region, when the number of group members increases - the bargaining effect.

Keywords: multiple blockholders; performance; minority expropriation; ownership structure; controlling group

JEL Classification: G32; G34

\section{Introduction}

Existing corporate finance literature dealing with the problem of ownership concentration compares a concentrated ownership structure with a large controlling shareholder with a dispersed ownership structure. ${ }^{1}$ In this literature, ownership concentration is seen as a mixed blessing. While a large controlling shareholder can monitor managers and mitigate manager-shareholder agency problems, the existence of control benefits means that it can also expropriate minority shareholders by diverting funds towards the generation of private benefits. ${ }^{2}$
Some firms, however, have a single controlling shareholder coexisting with smaller but significant shareholders, or even multiple large shareholders with an individual stake insufficient to warrant control, but which can form a controlling group if their aggregate equity stake exceeds $50 \%$ of the voting shares. Although such ownership structures can be observed among listed firms, they are especially prevalent in nonlisted firms. In fact, Faccio and Lang (2002) document the presence of at least two large shareholders in almost half of the firms in a sample of European firms.

\footnotetext{
*Corresponding author. E mail: joatribo@emp.uc3m.es

${ }^{1}$ Examples of seminal papers are Berle and Means (1932), Jensen and Meckling (1976), Grossman and Hart (1980), Schleifer and Vishny (1986) and Burkart et al. (1997).

${ }^{2}$ Barclay and Holderness (1989), Barclay et al. (1993) and Zingales (1994) measure private benefits indirectly by showing that large blocks of ownership that confer voting rights sell at a premium. Interestingly, Barclay et al. (1993) find that such premium exists even for some blocks which are not large enough to warrant firm control. This suggests that the benefits of control are divisible and can be shared among several large shareholders.
} 
Some papers address how controlling groups are formed between large shareholders (Zwiebel, 1995; Bennedsen and Wolfenzon, 2000) and their effect on monitoring (Pagano and Röell, 1998) and levels of private benefits extraction (Gomes and Novaes, 2005). However, little is known about how large shareholders interact and share their power and how the structure of the controlling group, i.e. its stake and number of members (blockholders), affects this dynamics. $^{3}$

This article uses detailed ownership data on Spanish firms to examine the determinants of the structure of controlling groups with multiple blockholders and how changes in this structure affect the performance of firms, in particular nonlisted firms.

We find that when firm characteristics promote minority expropriation, the composition of the controlling group is designed to hinder such behaviour. More specifically, after defining controlling group as a group of shareholders with enough votes to control the firm, we observe that for firms where expropriation seems more likely this group owns a higher stake in order to internalize expropriation costs. Moreover, performance increases significantly when the controlling group's stake is outside the region where expropriation is more likely, i.e. the $50-60 \%$ interval - the alignment effect - and, if within this region, when the number of group members increases - the bargaining effect. Finally, the existence of a noncontrolling (even if smaller) shareholder has a positive effect on performance when there is a single controlling blockholder with incentives to expropriate. This is related to the idea of contestability by which any (large enough) shareholder can contest the influence and monitor the actions of the controlling blockholder.

This article is related to others that look at the effect of multiple blockholders on firm market values (Volpin, 2002; Laeven and Levine, 2008), dividend policy (Faccio et al., 2001) and corporate governance (Korczak and Korczak, 2009). On the issue of contestability, Lehmann and Weigand (2000) show that the presence of a second large shareholder improves the profitability of German listed firms and Maury and Pajuste (2005) find that firm value increases using a sample of Finnish listed firms. Finally, Tribo and Casasola (2010) find that when banks form controlling coalitions between themselves there is a negative effect on firm returns. However, this negative effect does not exist when these coalitions are formed with other types of blockholders, i.e. when they form heterogeneous coalitions for which contestability is more likely.
In contrast to previous papers, we use a long panel database of mainly unlisted firms. By applying a dynamic panel data estimation method, we are able to separate the effect on performance due to changes in the number of blockholders (bargaining effect) from the effect due to changes in the blockholders' stake (alignment effect).

The remainder of this article is organized as follows. Section II states the hypotheses, Section III describes the data, Section IV presents the empirical analysis, and Section V concludes.

\section{Hypotheses Development}

\section{On the determinants of the ownership structure}

Regarding the ownership structure, Pagano and Röell (1998) predict that in firms with a single controlling shareholder, the ownership stake of the noncontrolling shareholders should be more concentrated when expropriation is likely to be severe so as to provide incentives for monitoring. In the case of firms with multiple controlling shareholders, Bennedsen and Wolfenzon (2000) and Gomes and Novaes (2005) predict that the controlling group should be larger and have a larger joint stake. In this way, it internalizes expropriating costs and minimizes the incentives for expropriation. Thus, our first hypothesis reads as follows:

Hypothesis 1: Firm characteristics that favour minority expropriation have a positive impact on the stake of the controlling blockholders.

\section{On the link between ownership structure and performance}

Firms are unlikely to be at their optimal capital structure due to wealth constraints faced by their owners, liquidity problems or vested interests of controlling parties (Bebchuk and Roe, 1999). Hence, we should expect a relationship between changes in ownership structure and performance.

Gomes and Novaes (2005) consider a setting in which the firm is controlled by a group of blockholders with veto power holding in aggregate the majority of the voting rights (controlling group). For a given ownership stake held by the controlling group, increasing the number of group members

\footnotetext{
${ }^{3}$ We use the terms 'blockholder(s)' and 'large shareholder(s)' interchangeably.
} 
generates a bargaining effect as it makes coordination on private benefit and rent extraction less likely. This leads us to propose that:

Hypothesis 2: For a given total stake held by the controlling group, increasing the number of controlling blockholders has a positive effect on performance.

According to Bennedsen and Wolfenzon (2000), the controlling group does not include all blockholders, but it results from a coalition formation game between the different blockholders which generates different coalitions that compete to seize control of the firm. More than one coalition can have sufficient voting power to control the firm. From an ex-ante point of view, the optimal coalition is the one with the largest ownership stake because of an alignment effect: it owns a greater portion of the firm's cash-flows which makes it more likely to internalize the effects of its own actions on the firm. This makes private benefit and rent extraction less likely, which leads to:

Hypothesis 3: For a given number of controlling blockholders, firm performance increases when the stake of the controlling group increases.

Pagano and Roëll (1998) consider a model with a manager who is simultaneously a blockholder and is monitored by other shareholders. In such setting, there is an optimal level of monitoring that is achieved given the stake of the second largest shareholder. This means that some shareholders outside the controlling group may also adopt a monitoring role and mitigate expropriation problems. In Bloch and Hege (2001), expropriation is lower in firms where control is more contestable, that is in firms in which the difference in blockholders' stakes is smaller or the stake in the hands of minority shareholders is larger. Therefore, our last hypothesis states that:

Hypothesis 4: Contestability, defined as the stake of the largest blockholder outside the controlling group, has a positive impact on firm performance.

\section{Data}

\section{Sample and variables}

We use the SABE database for the period between 1996 and 2006 from Bureau Van Dijk, which covers Spanish nonfinancial firms. We only consider firms that report their ownership structure and present detailed financial statements for at least three of the 11 years that we consider. From this, we obtain an incomplete panel with a total of 5287 different firms and 27221 firm-year observations for which we have information on direct ownership and on all the variables included in Table 1.

The sample includes three different types of firms: $1.2 \%$ are listed firms, $13.5 \%$ are closed firms and the remaining $85.3 \%$ are open, nonlisted firms.

Ownership structure and performance variables. Following Bennedsen and Wolfenzon (2000), we assume that a controlling group of blockholders determines firm decisions. ${ }^{4}$ They also show that of all the possible coalitions with a large enough stake to control the firm (a 50\% stake), the one that prevails ex-post has the minimum number of blockholders necessary to gain control (hereafter the Minimum Group) as this coalition maximizes the group of shareholders from whom to expropriate. We identify the Minimum Group and compute its total stake (Minimum Stake Group) and number of members (Members).

We characterize the ownership structure using five dummy variables: $0-25 \%, \quad 25-50 \%, \quad 50-60 \%$, $60-80 \%$ and $80-100 \%$, which take the value of 1 if the ownership stake of the controlling group is within each interval and 0 otherwise. ${ }^{5}$ Controlling groups with a $50-60 \%$ ownership stake are of particular interest because they have full control with relatively low cash-flow rights which makes them more likely to extract private benefits. ${ }^{6}$

An interaction term $50-60 \% \times i M$ with $i M$ $(i=1,2,3)$ reflecting the number of members of the controlling group $(1 M, 2 M, 3 M$ that correspond to 1 , 2 and 3 or more members, respectively) allows us to test the bargaining effect on which Hypothesis 2 is based. In order to test the alignment effect in Hypothesis 3, we interact the Minimum Stake Group

\footnotetext{
${ }^{4}$ A blockholder is any shareholder with an ownership stake of $1 \%$ or more. The results also hold for a 10 or $20 \%$ threshold (Faccio and Lang, 2002).

${ }^{5}$ Such cut offs arise naturally from the analysis conducted below (Table 4), which reveals that the stake of the controlling group that minimizes a firm's $R O A$ is within the $5060 \%$ interval. Under alternative cut off points such as $5075 \%$ and $75100 \%$, the qualitative results are unchanged.

${ }^{6}$ If pyramidal structures exist, expropriation can occur even for higher ownership stakes. And if there are dual class shares, expropriation can also occur when the stake is lower than $50 \%$. Under both situations, it is less likely to find a reduction in expropriation once we move away from the $5060 \%$ interval (Table 4). On the negative effects of dual class firms and pyramidal structures on firm value see, for example, Smith et al. (2009).
} 
Controlling group

Minimum group
Coalition formed by the minimum number of shareholders with an aggregate ownership stake larger than $50 \%$.

Ownership stake of controlling group

Minimum stake group Stake of the minimum group coalition.

Relative stake

A $B \%$

Absolute value of the difference between the minimum stake group and $50 \%$.

Dummy variable equal to 1 if the minimum stake group is in the $\mathrm{A} B \%$ range, and 0 otherwise. (A $0,25,50,60,80$; and B 25, 50,60,80, 100)

Number of members of the minimum group

Members $\quad$ Number of members of the minimum group.

$C M \quad$ Dummy variable equal to 1 if the number of members in the minimum group is equal to $\mathrm{C}$ and 0 otherwise. (C 1, 2 and 3 )

Additional ownership variables

Second

Stake of the second largest blockholder.

Performance variables

ROA

Tobinq

Net income over book value of assets.

Year end market value of equity plus book value of debt over book value of total assets.

Control variables

Size

Age

Intangibility

Listed

Leverage

Herfindahl

Growth

Types of firms

Type 1 firms

Type 2 firms

Type 3 firms

Small (large) firms

Closed (open) firms

Firm control firms Family control firms Other control firms
Logarithm of total assets.

Years since foundation.

Dummy variable equal to 1 if the firm is listed on the Madrid Stock Exchange, 0 otherwise.

Total book value of liabilities over total assets.

2 digit industry Herfindahl index of sales concentration.

2 digit industry $\%$ change in sales year on year.

Firms with a single blockholder.

Firms with a controlling group with two or more members, none with an individual majority stake.

Firms in which the largest blockholder controls the firm, owning more than $50 \%$ of the shares, and coexisting with (at least) a second large noncontrolling blockholder.

Firms in which Size is below (above) the mean of the distribution for the corresponding sector and year.

Firms in which outstanding shares can only (can) be sold to outsiders with (without) the approval of the incumbent shareholders.

Firms in which the largest blockholder is a firm.

Firms in which the largest blockholder is a family.

Firms in which the largest blockholder is neither a firm nor a family.
Intangible assets over total assets. variable with the aforementioned dummies $1 M, 2 M$ and $3 \mathrm{M}$. Finally, we interact the variable Second, which is the stake of the second largest shareholder, with the dummy $50-60 \% \times 1 M$ to test Hypothesis 4 .

We use return on assets (ROA) as our measure of firm performance.

Control variables. We hypothesize that private benefits extraction is more likely when monitoring costs are higher or there are more available internal resources. Following Demsetz and Villalonga (2001) and Morck et al. (1988), we use as proxies for the monitoring costs of a firm the variables Size, Age, Intangibility and Listed. We expect larger, younger, firms with more intangible assets, and unlisted firms to be more costly to monitor. Concerning the availability of internal resources, we use Leverage, Herfindahl index and Growth. We expect more leverage to reduce the availability of expropriation rents (or cash as in Ferreira and Vilela, 2004), and higher sales concentration and growth opportunities to increase them (Ueda, 2004).

\section{Descriptive statistics}

Table 2 shows some summary statistics. These numbers indicate that the ownership structure for the firms in our sample is highly concentrated given that in $89.70 \%$ of the cases, a group of blockholders has a stake greater than $50 \%$. We can divide firms into three groups. Type 1 firms with a single blockholder (63.73\%). Type 2 firms with several 


\section{Panel A}

\begin{tabular}{|c|c|c|c|c|c|c|c|c|}
\hline & \multirow[b]{2}{*}{ Mean } & \multirow[b]{2}{*}{ Median } & \multirow[b]{2}{*}{$\mathrm{SD}$} & \multicolumn{5}{|c|}{ Mean values in the following stake intervals } \\
\hline & & & & $025 \%$ & $2550 \%$ & $5060 \%$ & $6080 \%$ & $80 \quad 100 \%$ \\
\hline Own. Distribution & & & & $5.70 \%$ & $4.60 \%$ & $17.16 \%$ & $15.99 \%$ & $56.55 \%$ \\
\hline Stake & $77.40 \%$ & $89.90 \%$ & 0.266 & $11.5 \%$ & $36.5 \%$ & $51.9 \%$ & $69.4 \%$ & $97.4 \%$ \\
\hline Members & 1.221 & 1 & 0.611 & 1.345 & 1.322 & $1.580 * * *$ & 1.426 & 1.033 \\
\hline Second & $10.50 \%$ & 0 & 0.158 & $0.8 \%$ & $25.1 \%$ & $24.9 \% * * *$ & $22.5 \%$ & $2.6 \%$ \\
\hline \multicolumn{9}{|l|}{ Performance } \\
\hline$R O A$ & 0.077 & 0.065 & 0.260 & 0.077 & 0.091 & $0.075 * *$ & 0.078 & 0.076 \\
\hline Tobing & 1.710 & 1.517 & 4.232 & 0.534 & 1.350 & $1.145^{*}$ & 1.259 & 2.156 \\
\hline \multicolumn{9}{|l|}{ Controls } \\
\hline Size & 16.056 & 15.980 & 1.320 & 15.966 & 15.767 & 15.964 & 15.934 & $16.151 * * *$ \\
\hline Age & 21.891 & 19 & 13.818 & 24.848 & 19.933 & 22.543 & 21.681 & $21.614 * *$ \\
\hline Intangibility & 0.135 & 0.169 & 0.208 & 0.121 & 0.128 & 0.138 & 0.141 & 0.134 \\
\hline Listed & 0.011 & 0 & 0.047 & 0.02 & 0.02 & 0.010 & 0.001 & $0.001 * * *$ \\
\hline Leverage & 0.573 & 0.591 & 0.991 & 0.539 & 0.554 & 0.558 & 0.597 & 0.575 \\
\hline Herfindahl & 0.019 & 0.010 & 0.119 & 0.015 & 0.019 & 0.018 & 0.018 & $0.020 * * *$ \\
\hline Growth & 0.040 & 0.039 & 0.018 & 0.041 & 0.040 & 0.040 & 0.040 & 0.040 \\
\hline
\end{tabular}

\begin{tabular}{|c|c|c|c|c|c|c|c|c|}
\hline & \multirow[b]{2}{*}{ Obs. $(\%)$} & \multirow[b]{2}{*}{ Stake } & \multirow[b]{2}{*}{ ROA } & \multicolumn{5}{|c|}{ Distribution of firms in each interval (min. stake group) } \\
\hline & & & & $025 \%$ & $2550 \%$ & $5060 \%$ & $6080 \%$ & $80100 \%$ \\
\hline \multicolumn{9}{|l|}{ Type of firms } \\
\hline Type 1 & $63.73 \%$ & $85.5 \% * * *$ & $0.075 * *$ & $7.31 \%$ & $4.58 \%$ & $3.66 \%$ & $4.16 \%$ & $80.29 \%$ \\
\hline Type 2 & $14.34 \%$ & $58.7 \%$ & 0.081 & $7.25 \%$ & $11.72 \%$ & $29.15 \%$ & $38.98 \%$ & $12.90 \%$ \\
\hline Type 3 & $21.93 \%$ & $65.9 \%$ & 0.079 & $0.00 \%$ & $0.00 \%$ & $48.56 \%$ & $35.34 \%$ & $16.10 \%$ \\
\hline Small & $50.84 \%$ & $75.3 \% * * *$ & $0.078 *$ & $5.77 \%$ & $4.95 \%$ & $19.69 \%$ & $17.45 \%$ & $52.14 \%$ \\
\hline Large & $49.16 \%$ & $79.5 \%$ & 0.075 & $5.64 \%$ & $4.25 \%$ & $14.55 \%$ & $14.47 \%$ & $61.09 \%$ \\
\hline Closed & $13.56 \%$ & $81.8 \% * * *$ & $0.070 * *$ & $3.24 \%$ & $3.39 \%$ & $15.19 \%$ & $13.64 \%$ & $64.54 \%$ \\
\hline Open & $86.44 \%$ & $76.7 \%$ & 0.078 & $6.10 \%$ & $4.79 \%$ & $17.47 \%$ & $16.35 \%$ & $55.29 \%$ \\
\hline Firm control & $45.41 \%$ & $79.1 \%$ & 0.077 & $6.32 \%$ & $5.48 \%$ & $13.94 \%$ & $12.27 \%$ & $61.99 \%$ \\
\hline Family control & $27.76 \%$ & $74.2 \% * * *$ & $0.082 * * *$ & $4.07 \%$ & $3.03 \%$ & $24.28 \%$ & $21.94 \%$ & $46.68 \%$ \\
\hline Other control & $26.83 \%$ & $77.7 \%$ & 0.072 & $6.37 \%$ & $4.73 \%$ & $15.28 \%$ & $16.10 \%$ & $57.52 \%$ \\
\hline
\end{tabular}

Notes: Variables are as defined in Table 1. In Panel A, the counterparts are the other controlling group stake intervals than that of reference, whether the $5060 \%$ interval (for the variables of ownership distribution and performance) or the $80100 \%$ (for the control variables). Number of observations: 27221 (5287 firms), except for Tobinq (listed firms), where the number of observations is 325 (63 firms). In Panel B, the counterparts for the variables Stake and ROA are the other type of firms than that of reference (i.e. Type 1 versus non Type 1, Small versus Large, Closed versus Open, Family control versus non Family control).

$*, * *$ and $* * *$ denote significance at 10, 5 and $1 \%$ levels, respectively, of the $t$ test between one category and the corresponding counterparts.

blockholders sharing control since their individual stakes are lower than $50 \%(14.34 \%)$. Type 3 firms with one controlling blockholder with a stake exceeding $50 \%$, which coexists with other blockholders $(21.93 \%)$.

In terms of profitability, as measured by $R O A$, the lowest value $(7.5 \%)$ appears when the controlling group's stake lies within the $50-60 \%$ interval. Note that this is precisely the interval in which expropriation is most likely to occur. Moreover, firm profitability is greater for Type $2(8.1 \%)$ than for
Type 3 firms (7.9\%). Type 1 firms are the least profitable according to this table $(7.5 \%)$. These results are encouraging in the sense that they suggest that there is a positive relationship between the number of controlling blockholders and firm profitability.

The table also shows that firms whose controlling group's stake lies in the $80-100 \%$ interval are larger, younger, tend to be nonlisted and compete in a more concentrated sector (larger Herfindahl index) than firms in the other stake intervals. This result 
is consistent with a higher expropriation risk, which is mitigated by the large stake of the controlling group.

\section{Multivariate Analysis}

\section{Methodology}

To study the determinants of ownership structure, we estimate the following model:

$$
\begin{aligned}
& \text { Relative Stake }_{i t} \\
& =\alpha_{1}+\alpha_{2} \text { Relative Stake }_{i t} 1 \\
& +\alpha_{3} \text { ROA }_{i t}{ }_{1}+\alpha_{4} \text { Size }_{i t}+\alpha_{5} \mathrm{Age}_{i t} \\
& +\alpha_{6} \text { Intangibility }_{i t}+\alpha_{7} \text { Listed }_{i t} \\
& +\alpha_{8} \text { Leverage }_{i t}+\alpha_{9} \text { Herfindahl }_{i t} \\
& +\alpha_{10} \text { Growth }_{i t}+\gamma_{i}+\varepsilon_{t}
\end{aligned}
$$

We expect larger values of Relative Stake in firms with higher risk of minority expropriation. This risk increases with the potential expropriating rents (proxied by Leverage, Herfindahl and Growth), and the harder it is to prevent expropriation due to, for example, high monitoring costs (proxied by Size, Age, Intangibility and Listed). The specification also includes the lagged value of the dependent variable, Relative Stake, so as to allow for adjustments in the ownership structure, lagged firm performance, $R O A$, in order to tackle potential endogeneity problems as discussed below, and industry and year dummy variables.

To study performance, as measured by $R O A$, we estimate the following model:

$$
\begin{aligned}
\text { ROA }_{i t}= & \beta_{1}+\beta_{2} \text { ROA }_{i t} 1 \\
& +\beta_{3} \text { Minimum Stake Group Variables }_{i t}+\beta_{4} \text { Size }_{i t} \\
& +\beta_{5} \text { Age }_{i t}+\beta_{6} \text { Intangibility }_{i t}+\beta_{7} \text { Listed }_{i t} \\
& +\beta_{8} \text { Leverage }_{i t}+\beta_{9} \text { Herfindhal }_{i t} \\
& +\beta_{10} \text { Frowth }_{i t}+\gamma_{i}^{\prime}+\varepsilon_{t}^{\prime}
\end{aligned}
$$

Apart from the variables in model (1), we also include variables that characterize the ownership and controlling group structures.

While conducting the estimations, we face two important econometric issues. The first is a potential omitted variable problem. We tackle this problem by: (i) including in the estimations all the observable time variant characteristics that we think may be simultaneously correlated with performance and ownership and (ii) exploiting the panel data structure of our sample and estimate in differences in order to control for all time invariant firm characteristics.
The second problem is reverse causality. In specification (1), we tackle this problem by lagging the variable of performance, $R O A$, by one period, and conducting system General Method of Moments (GMM) estimations (Arellano and Bond, 1991). In specification (2), we repeat the GMM estimations and instrument as follows the ownership structure dummies - 0-25\%, 25-50\%, 50-60\%, 60-80\%, 80-100\%. We create a set of dummy instruments such that the dummy instrument $\mathrm{A}-\mathrm{B} \%$ is equal to one when two conditions are met: (i) the stake of the controlling group falls within the $\mathrm{A}-\mathrm{B} \%$ interval and (ii) the predicted value of the stake of the controlling group computed using the coefficient of the variable of performance from specification (1) falls outside the $\mathrm{A}-\mathrm{B} \%$ interval. Note that these instruments are uncorrelated with performance - the dependent variable - given that performance does not explain when the stake of a controlling group falls within a given $\mathrm{A}-\mathrm{B} \%$ interval. However, these instruments are correlated with the stake of the controlling group - by condition (i). Finally, as one of the instruments in the GMM estimation, we use the dependent variable lagged two periods and, when possible, up to three period lags in the explanatory variables.

\section{Determinants of the structure of the controlling group}

The estimation of specification (1) is the first step of the two-stage approach described in the previous section. This estimation allows for contrasting Hypothesis 1.

The results in column 3 of Table 3 indicate that as firms become more difficult to monitor (larger, younger and nonlisted firms), there is an increase in the stake of the controlling group. We find no significant results regarding the availability of internal resources (less leveraged and high growth firms and firms in concentrated industries). Overall, the results partially confirm Hypothesis 1. Firms with different characteristics seem to adjust the composition of their controlling groups so as to prevent minority expropriation problems. However, this adjustment is not perfect, given the significant coefficient on the lagged variable Relative Stake.

\section{Performance effects of the structure of the control- ling group}

The second stage of the estimation design described in the 'Methodology' section contrasts firm performance.

The results from column 1 of Table 4 confirm that there is a U-shaped relationship between the stake of 


\begin{tabular}{|c|c|c|c|}
\hline Type of estimation & Cross section & Fixed effect estimation & System GMM estimation \\
\hline Relative Stake ( 1) & & & $0.268 * *(2.030)$ \\
\hline$R O A(1)$ & $0.071 * * *(3.350)$ & $0.027 * *(1.900)$ & $0.137 * * *(2.570)$ \\
\hline Size & $0.022 * * *(9.670)$ & $0.018 * *(1.800)$ & $0.012 * *(2.010)$ \\
\hline Age & $0.001 * * *(5.970)$ & $0.001 *(1.710)$ & $0.001 * *(1.890)$ \\
\hline Intangibility & $0.001(0.030)$ & $0.001(0.770)$ & $0.001(0.500)$ \\
\hline Listed & $0.188 * * *(5.930)$ & $0.137(0.250)$ & $0.119 * * *(2.710)$ \\
\hline Leverage & $0.001(0.670)$ & $0.001(0.790)$ & $0.001(0.920)$ \\
\hline Herfindahl & $0.010(0.024)$ & $0.066(0.580)$ & $0.010(0.030)$ \\
\hline Growth & $0.007 * * *(3.400)$ & $0.047 *(1.650)$ & $0.036(0.200)$ \\
\hline Intercept & $0.242 * * *(9.960)$ & $0.213 * * *(2.390)$ & $0.204(0.620)$ \\
\hline Number of observations & 27221 & 27221 & 27221 \\
\hline Fitness test & $153.10(0.000)$ & $34.75(0.000)$ & $195.89(0.000)$ \\
\hline Hausman test & & $52.03(0.000)$ & \\
\hline AR (2) test & & & $1.53(0.225)$ \\
\hline Hansen overidentification test & & & $21.12(0.451)$ \\
\hline
\end{tabular}

Notes: The dependent variable is the Relative Stake of the controlling group. All variables are defined in Table 1. All regressions include industry and year dummies. The $F$ test is used as a fitness test for the cross section and the fixed effect estimation, while the Wald test is used for the system GMM estimation. The Hausman test has the identity between the coefficients of the random effects estimation and the fixed effects estimation as null hypothesis. The AR(2) is a test for a second order serial correlation in the residuals which is distributed as $N(0,1)$ under the null hypothesis of no serial correlation. For the Hansen test, the $J$ statistic is distributed as a chi squared under the null hypothesis of instrument validity ( $p$ values reported in parentheses).

$*, * *$ and $* * *$ denote significance at 10,5 and $1 \%$ levels, respectively ( $t$ values in parentheses).

the controlling group and performance, with the minimum for a controlling group stake of $53.7 \%{ }^{7}$ Hence, it makes sense to think of the interval between $50-60 \%$ as the potential expropriating region. Column 2 shows that the coefficient of the interaction between the $50-60 \%$ stake dummy and the $1 M$ dummy is negative and significant. ${ }^{8}$ Moreover, the results indicate that firms moving to a controlling group with an ownership stake in the $50-60 \%$ interval but with more than one coalition member perform better than the control group of firms in the $80-100 \%$ interval. Therefore, the presence of multiple controlling shareholders reduces expropriation risk once we fix the stake of the controlling group. This provides support for Hypothesis 2, and can be interpreted as evidence of the bargaining effect. In order to contrast Hypothesis 4, we interact the variable $50-60 \% \times 1 M$ with the Second variable. The coefficient is positive, supporting Hypothesis 4.

Finally, the results from column 3 confirm Hypothesis 3; once the number of blockholders is fixed, the performance increases with the stake of the controlling group. ${ }^{9}$

\section{Conclusions}

We perform an empirical evaluation of the role of concentrated ownership structures with multiple blockholders, for a sample of mainly nonlisted Spanish firms covering the period from 1996 to 2006. We find that ownership structure is highly concentrated with many firms having multiple

${ }^{7}$ This is the result of computing Coefficient (Minimum Stake Group)/[2× Coefficient (Minimum Stake Group $\left.\left.(\wedge 2)\right)\right] \quad 0.202 /$ $2 \times 0.188 \quad 53.7 \%$.

${ }^{8}$ If a firm in the $80 \quad 100 \%$ interval (the reference interval) has an $R O A$ of $7.7 \%$ (the sample mean from Table 2 ), a similar firm with one controlling shareholder with an ownership stake in the $5060 \%$ interval has an $R O A$ of $6.9 \%(7.70 .8 \%)$. This corresponds to a relative drop of more than $10 \%$.

${ }^{9}$ In unreported results, we conduct an analysis for the sample of listed firms using Tobinq as a performance measure. We find three main results. First, there is $U$ shaped relationship between the stake of the controlling group and Tobinq. The minimum performance value corresponds to a controlling group stake of $36.32 \%$, which means that expropriation risk is maximized in the $2550 \%$ region. Second, the presence of a second blockholder, even if outside the controlling coalition, plays a positive contestability role, which confirms Hypothesis 4. In addition, the presence of more than one blockholder in a controlling coalition in the $5060 \%$ region has a positive effect on performance, which conforms to Hypothesis 2 . Third, we find evidence of an alignment effect, regardless of the number of blockholders in the controlling coalition, which conforms to Hypothesis 3. 
Table 4. Performance in terms of ownership structure (system GMM estimation)

\begin{tabular}{|c|c|c|c|}
\hline$R O A(1)$ & $0.148 * *(2.080)$ & $0.340 * * *(7.090)$ & $0.260 * * *(2.480)$ \\
\hline Minimum Stake Group & $0.202 * *(1.910)$ & & \\
\hline Minimum Stake Group $(\wedge 2)$ & $0.188 * *(2.030)$ & & \\
\hline $025 \%$ & & $0.034 *(1.730)$ & \\
\hline $2550 \%$ & & $0.019 * * *(2.880)$ & \\
\hline $5060 \% \times 1 M$ & & $0.008 * * *(2.220)$ & \\
\hline $5060 \% \times 1 M \times$ Second & & $0.035 * * *(3.250)$ & \\
\hline $5060 \% \times 2 M$ & & $0.017 * * *(2.270)$ & \\
\hline $5060 \% \times 3 M$ & & $0.032 * * *(3.510)$ & \\
\hline $6080 \%$ & & $0.034 * * *(3.800)$ & \\
\hline Minimum Stake Group $\times 1 M$ & & & $0.048 * * *(2.590)$ \\
\hline Minimum Stake Group $\times 2 M$ & & & $0.051 * *(2.030)$ \\
\hline Minimum Stake Group $\times 3 M$ & & & $0.039(1.370)$ \\
\hline Size & $0.171 * * *(2.430)$ & $0.127 * * *(2.780)$ & $0.162 * *(1.840)$ \\
\hline Age & $0.001(0.060)$ & $0.001 *(1.730)$ & $0.001 * *(2.280)$ \\
\hline Intangibility & $0.001(0.980)$ & $0.001 * * *(2.880)$ & $0.001 *(1.750)$ \\
\hline Listed & $0.008(0.080)$ & $0.004(0.370)$ & $0.009 * * *(2.990)$ \\
\hline Leverage & $0.002(0.110)$ & $0.002 * *(2.110)$ & $0.001 * * *(2.280)$ \\
\hline Herfindahl & $0.038(1.020)$ & $0.060(1.090)$ & $0.142 * *(2.070)$ \\
\hline Growth & $0.214(0.810)$ & $0.280(0.760)$ & $0.202 * *(2.250)$ \\
\hline Intercept & $0.077(0.219)$ & $0.070 * * *(3.130)$ & $0.071(0.220)$ \\
\hline Number of observations & 27221 & 27221 & 27221 \\
\hline Fitness test & $95.48(0.000)$ & $537.95(0.000)$ & $739.94(0.000)$ \\
\hline AR (2) test & $0.71(0.476)$ & $1.15(0.251)$ & $0.86(0.391)$ \\
\hline Hansen overidentification test & $96.56(0.905)$ & $180.31(0.563)$ & $150.00(0.812)$ \\
\hline
\end{tabular}

Notes: The dependent variable is $R O A$. ROA ( 1$)$ is the variable $R O A$ lagged by one period. Minimum Stake Group $(\wedge 2)$ is Minimum Stake Group squared. The remaining variables are defined in Table 1. All the regressions include industry and year dummies. The Wald test is used as a fitness test. The AR(2) is a test for a second order serial correlation in the residuals which is distributed as $N(0,1)$ under the null hypothesis of no serial correlation. For the Hansen overidentification test, the $J$ statistic is distributed as a chi square under the null hypothesis of instrument validity ( $p$ values reported in parentheses).

$*, * *$ and $* * *$ denote significance at 10,5 and $1 \%$ levels, respectively ( $t$ values in parentheses).

blockholders with aggregate ownership stakes larger than $50 \%$.

Firms that face a serious threat of minority expropriation due to higher monitoring costs (as measured by firm size, age and listing status) tend to have controlling group equity stakes that are far from the $50 \%$ threshold, where expropriation is expected to be higher. Moreover, for a given controlling group's stake in the $50-60 \%$ interval of maximum expropriation risk, increases in the number of controlling blockholders in the group have a positive effect on performance. We interpret this as evidence of bargaining for private benefits among blockholders. For a given number of controlling blockholders, increases in their aggregate stake result in improved performance. We regard this as evidence of an alignment effect between the interests of blockholders and those of minority shareholders, as the stake of the controlling group increases. Finally, having blockholders outside the controlling group has a positive effect on performance. They can reduce expropriation by performing a monitoring role and boosting the contestability of the ownership structure.
Overall, our results confirm the need to take into account the structure of blockholders controlling groups when studying the impact of ownership on performance. They also indicate that minority expropriation in nonlisted firms is an important problem that has not received sufficient attention from empirical researchers, who focus mainly on listed firms.

\section{Acknowledgements}

The authors wish to thank Arturo Bris, Francisco González, Rafael Repullo, Andrei Shleifer, the participants at seminars at Universidad Carlos III and Universidad de Oviedo, at the conference on 'Corporate Finance and Governance of Privately Held Firms' (Oslo, 2008) and the 'Workshop of Corporate Governance' (Copenhagen, 2005) for their valuable comments and suggestions. Financial support of Comunidad de Madrid (Grants 2008/00037/ 001 and 2009/00138/001) and the Spanish Ministry of Education and Science (Grants SEJ2006-01731, 
SEJ2006-09401, ECO2009-10796 and CSD2006-16) is gratefully acknowledged. The usual disclaimers apply.

\section{References}

Arellano, M. and Bond, S. (1991) Some tests of specifica tion for panel data: Monte Carlo evidence and an application to employment equations, Review of Economic Studies, 58, 27797.

Barclay, M. and Holderness, C. G. (1989) Private benefits from control of public corporations, Journal of Financial Economics, 25, 37195.

Barclay, M., Holderness, C. G. and Pontiff, J. (1993) Private benefits from block ownership and discounts on closed end funds, Journal of Financial Economics, 33, 26391.

Bebchuk, L. A. and Roe, M. J. (1999) A theory of path dependence in corporate ownership and governance, Stanford Law Review, 52, 12770.

Bennedsen, M. and Wolfenzon, D. (2000) The balance of power in close corporations, Journal of Financial Economics, 58, 11339.

Berle, A. and Means, G. (1932) The Modern Corporation and Private Property, Macmillan, New York.

Bloch, F. and Hege, U. (2001) Multiple shareholders and control contests, GREQAM, Working Paper No. 01A16. Available at http://greqam.univ mrs.fr/IMG/ working_papers/2001/01a16.pdf (accessed 29 May 2012).

Burkart, M., Gromb, D. and Panunzi, F. (1997) Large shareholders, monitoring and the value of the firm, Quarterly Journal of Economics, 112, 693728.

Demsetz, H. and Villalonga, B. (2001) Ownership structure and corporate performance, Journal of Corporate Finance, 7, 20933.

Faccio, M. and Lang, L. H. P. (2002) The ultimate ownership of Western European corporations, Journal of Financial Economics, 65, 36595.

Faccio, M., Lang, L. H. P. and Young, L. (2001) Dividends and expropriation, American Economic Review, 91, 5478.

Ferreira, M. A. and Vilela, A. S. (2004) Why do firms hold cash? Evidence from EMU countries, European Financial Management, 10, 295319.

Gomes, A. R. and Novaes, W. (2005) Sharing of control as a corporate governance mechanism, PIER Working Paper No. 112.
Grossman, S. and Hart, O. (1980) Takeover bids, the free rider problem and the theory of the corporation, Bell Journal of Economics, 11, 4264.

Jensen, M. and Meckling, W. (1976) Theory of the firm: managerial behaviour, agency costs and ownership structure, Journal of Financial Economics, 3, 30560 .

Korczak, A. and Korczak, P. (2009) Corporate ownership and the information content of earnings in Poland, Applied Financial Economics, 19, 70317.

Laeven, L. and Levine, R. (2008) Complex ownership structures and corporate valuations, Review of Financial Studies, 21, 579604.

Lehmann, E. and Weigand, J. (2000) Does the governed corporation perform better? Governance structures and corporate performance in Germany, European Finance Review, 4, 15795.

Maury, B. and Pajuste, A. (2005) Multiple large share holders and firm value, Journal of Banking and Finance, 29, 181335.

Morck, R., Shleifer, A. and Vishny, R. (1988) Management ownership and market valuation: an empirical analy sis, Journal of Financial Economics, 20, 293315.

Pagano, M. and Roëll, A. (1998) The choice of stock ownership structure: agency costs, monitoring and the decision to go public, Quarterly Journal of Economics, 113, 187225.

Schleifer, A. and Vishny, R. (1986) Large shareholders and corporate control, Journal of Political Economy, 94, 46188.

Smith, B. F., Amoako Adu, B. and Kalimipalli, M. (2009) Concentrated control and corporate value: a comparative analysis of single and dual class structures in Canada, Applied Financial Economics, 19, 95574.

Tribo, J. A. and Casasola, M. J. (2010) Banks as firms' blockholders: a study in Spain, Applied Financial Economics, 20, 42538.

Ueda, M. (2004) Banks versus venture capital: project evaluation, screening and expropriation, The Journal of Finance, 49, 60121.

Volpin, P. F. (2002) Governance with poor investor protection: evidence from top executive turnover in Italy, Journal of Financial Economics, 64, 6190.

Zingales, L. (1994) The value of the voting right: a study of the Milan Stock Exchange experience, Review of Financial Studies, 7, 12548.

Zwiebel, J. (1995) Block investment and partial benefits of corporate control, Review of Economic Studies, 62, 16185. 